\title{
Endoscopic Retrograde \\ Cholangiopancreatography in a Patient with Situs Inversus Totalis
}

\author{
Situs Inversus Totalis Olgusunda Endoskopik Retrograd \\ Kolanjiopankreatografi Uygulaması \\ (D) Hakan Erpek ${ }^{1}$, (1) Pars Tunçyürek ${ }^{2}$
}

\author{
${ }^{1}$ Girne University Dr. Suat Günsel University Faculty of Medicine, Deparment of General Surgery, Kyrenia, North Cyprus \\ ${ }^{2}$ Aydın Adnan Menderes University Faculty of Medicine, Deparment of General Surgery, Aydın, Turkey
}

Keywords

Cholangiopancreatography, endoscopic

retrograde, gallstones, situs inversus

Anahtar Kelimeler

Kolanjiopankreatografi, endoskopik

retrograd, safra taşları, situs inversus

Received/Geliş Tarihi : 14.05.2017

Accepted/Kabul Tarihi : 17.05.2017

doi:10.4274/meandros.galenos.2017.19484

Address for Correspondence/Yazışma Adresi: Hakan Erpek MD,

Girne University Dr. Suat Günsel University Faculty of Medicine, Deparment of General Surgery, Kyrenia, North Cyprus

Phone : +905326532313

E-mail : hakanerpek@yahoo.com

ORCID ID: orcid.org/0000-0002-4806-4703

(C) Meandros Medical and Dental Journal, Published by Galenos Publishing House.

This is article distributed under the terms of the Creative Commons Attribution NonCommercial 4.0

International Licence (CC BY-NC 4.0).

\begin{abstract}
Endoscopic retrograde cholangiopancreatography (ERCP) technique is a widely accepted procedure in treating obstructing diseases of the common bile duct. The equipment and instruments of which are designed for patients with common anatomic features. The variations of anatomic landmarks make the procedure more demanding. A rare congenital situation, situs inversus totalis (SIT), is the mirror image placement of abdominal and thoracic viscera. The vice versa placement of intra-abdominal organs requires the technical change of standard maneuvers and setup when a need of the ERCP procedure arises. This case report emphasizes these changes in the ERCP procedure of a patient with common bile duct stone and SIT.
\end{abstract}

Öz

Endoskopik retrograd kolanjiopankreatografi (ERKP) tekniği ana safra yollarını tıkayan hastalıkların tedavisinde yaygın kabul görmüş tedavi yöntemidir. ERKP işlemi için kullanılan cihaz ve aletler genel anatomik özellikleri olan hastalar için tasarlanmıştır. Anatomik farkıııkları olan hastalarda bu işlemi gerçekleştirmek daha zordur. Nadir bir konjenital durum olan situs inversus totalis (SiT) toraks ve abdomen içi organların aynadaki akis gibi yer değişmesidir. Karın içi organların ters yönde oluşması ERKP gerektiğinde standart manevra ve düzenden farklılıklar gerektirir. Bu olgu sunumu koledokta taşı olan bir SiT hastasında ERKP işlemi sırasındaki bu değişikliklere vurgu yapmaktadır.

\section{Introduction}

The usual position of organs in abdomen and chest are called as situs solitus whereas situs inversus is the mirror image reversal of this normal positioning. Situs inversus totalis (SIT) in humans was described in $16^{\text {th }}$ century by Matthew Baillie although Aristotle was the first to detect this kind of positioning in animals centuries ago (1). The incidence of SIT was suggested to be in the range of $1: 10,000$ to $1: 20,000$ and generally it is an autosomal recessive genetic condition (2). 
Endoscopic retrograde cholangiopancreatography (ERCP) technique was described in diagnosis and treatment various common bile duct disorders in 1970s and since then it had gradually become widespread and a gold standard throughout the world. When a patient with SIT has a common bile duct disorder requiring an ERCP procedure, this technique is feasible with some challenging modified maneuvers. A situs inversus case requiring ERCP and subsequent laparoscopic cholecystectomy was reported in this article.

\section{Case Report}

\section{The Patient}

Twenty seven year old female patient with obstructive jaundice was referred from a local secondary health center diagnosed as gall bladder and common bile duct stone disease. The patient was previously known as a situs inversus case. She had suffered left upper quadrant pain for a few day accompanied by darkening urine color. The laboratory study revealed elevated liver function tests and total/ direct bilirubin level were $3.4 / 2.6 \mathrm{mg} / \mathrm{dL}$ respectively. Ultrasonography work reported gall bladder stones with dilated common and intrahepatic bile ducts without signs of acute cholecystitis and magnetic resonance cholangiopancreatography revealed a 4-mm stone located distally in common bile duct. She was hospitalized for an urgent ERCP procedure and subsequent elective laparoscopic cholecystectomy. After obtaining patient's consent, both procedures were performed by the authors.

Endoscopic Retrograde

\section{Cholangiopancreatography Technique}

The patient was positioned as left semi prone on the procedure table after pharyngeal local anesthetic spray was introduced as usual. The patient was sedated with propofol and phentanyl by an anesthesiologist. The endoscopist was located on the right side of the table holding the patient at his left and monitor at his front as usual. The duodenoscope (Pentax ED 3490TK with $3.8 \mathrm{~mm}$ working channel) introduced as usual until entrance to corpus of stomach. At this moment, in order to make an- $180^{\circ}$ counterclockwise rotation at the tip of duodenoscope, the endoscopist turned to his left about $180^{\circ}$ and positioned the patient at his right and monitor at his almost rear side (Figure
1). This maneuver helped the tip of duodenoscope to advance antrum and pylorus. After reaching $2^{\text {nd }}$ part of duodenum, usual short scope position to face papilla in front was not possible. So, the endoscopist needed to push the duodenoscope to be at long scope position and made him stay bended forward to keep papilla at near front (Figure 2). The tip of

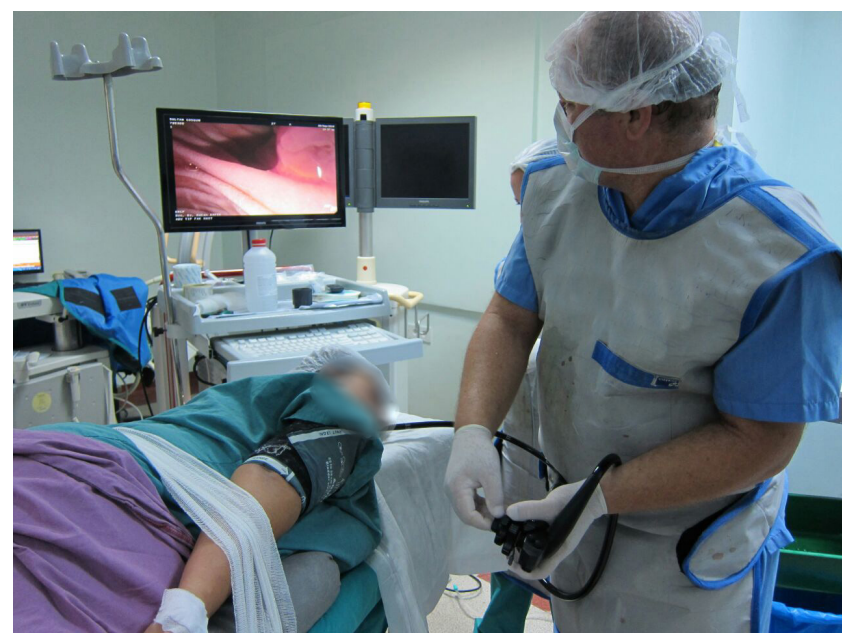

Figure 1. The initial change of position when endoscope is in stomach to find pylorus

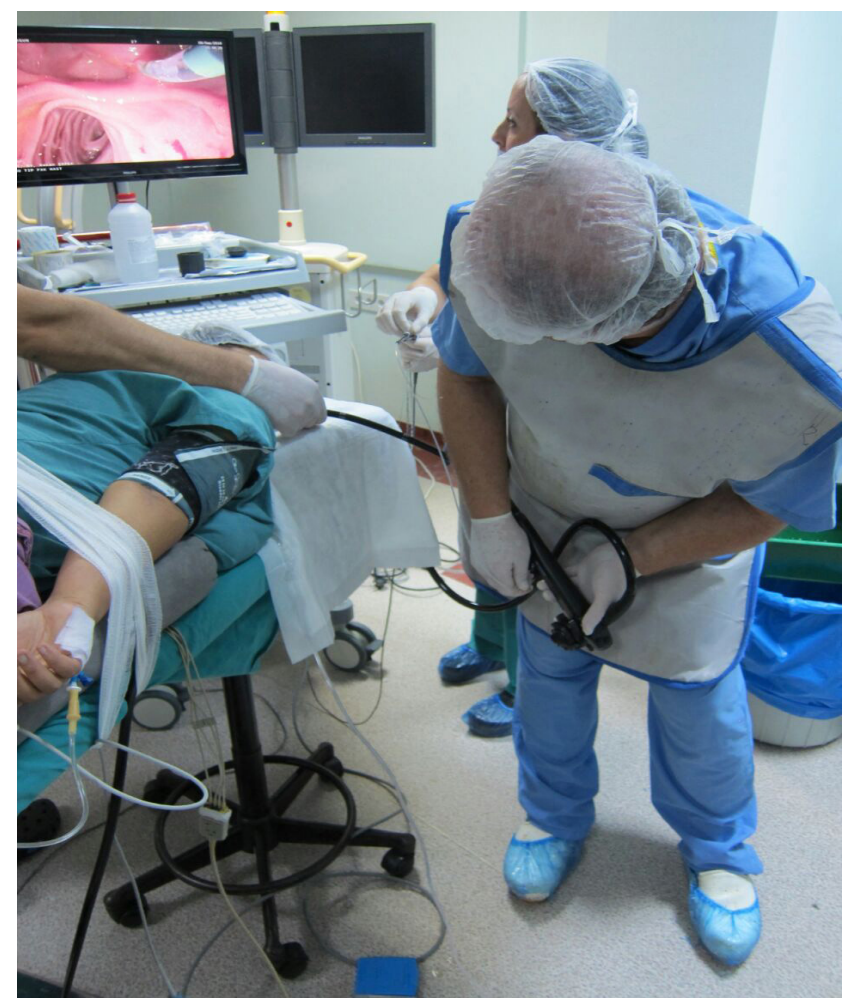

Figure 2. The position of the endoscopist to localize papilla after entrance into duodenum 
papilla was blocked by a stone and catheterized by a-3 lumen sphincterotome by keeping this endoscopist's position steady. The cholangiography showed a single mobile radiopacity, slightly dilated common bile duct. After endoscopic sphincterotomy, a-3-4 mm stone spontaneously drop into the duodenum (Figure 3). The procedure was stopped after exploration of common bile duct with a stone extraction balloon catheter and control cholangiography revealed no abnormal findings. The post procedural period was uneventful and blood bilirubin levels dropped and the patient was discharged next day with a scheduled laparoscopic cholecystectomy 10 days later.

\section{Discusssion}

ERCP in patients with SIT has demanding technical difficulties because of the right and left reversal. To overcome these difficulties some technical modifications of conventional ERCP technique requiring changes in the position of the patient at the beginning, during the procedure $(3,4)$ and altered position of the endoscopist were proposed in case presentations $(5,6)$. Since these patients are rare, it is not easy for an endoscopist to get experience of every modification to compare them with each other. After reviewing these modifications throughout the literature publications, it was deduced that the best approach was the most usual one. This approach may help the avoidance of adaptation problems in mirror image positions and need of multiple changes of patient's position on the procedure table. The positional changes of the endoscopist made the screen image as possible as usual.

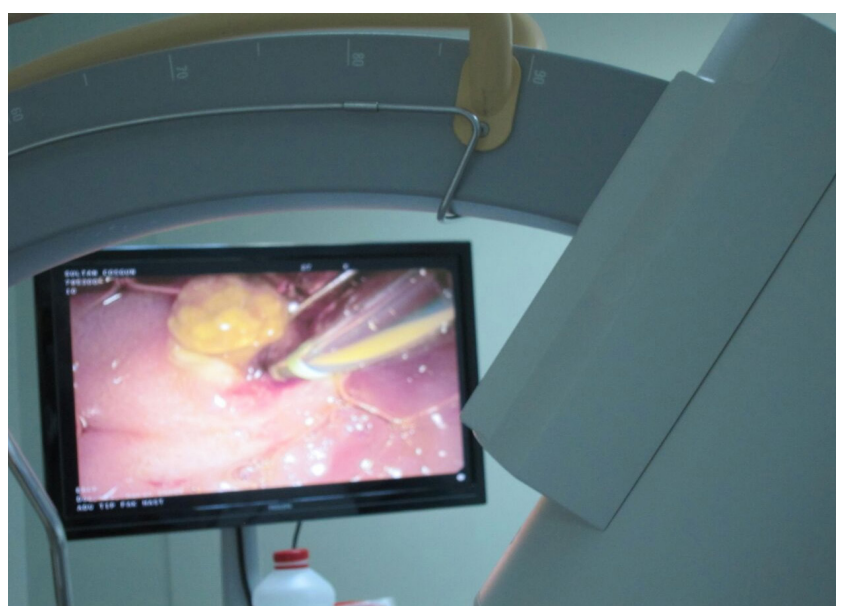

Figure 3. The removed stone after sphincterotomy
Our approach required usual set up and initiation of the procedure. Once the duodenoscope was within the stomach, since patient's viscera was vice versa, optical eye of the endoscope showed posterior wall of the organ instead of anterior as in a usual case. Therefore, a- $180^{\circ}$ anticlockwise twist of the endoscope was needed to point the tip towards antrum and pylorus. This extreme twist of endoscope required turning the endoscopist to the same direction and degree as well. It was the first positional change of the endoscopist. After entering duodenum, the optical eye duodenoscope showed the posterolateral wall of the duodenum instead of facing papilla at the medial side. So endoscopist needed to bend forward in order to make a more than $90^{\circ}$ anticlockwise twist of the tip to enface papilla. This position was the second change of endoscopist's position. Since the cannulization of the papilla is one of the most challenging steps of ERCP, catheterization of common bile duct had to be performed at Picture position.

Even though the mentioned twisting maneuvers seemed to make the procedure become challenging, we believe that other options have more adaptation issues than this approach.

Even though there are different technical approaches for a common bile duct stone in a patient with SIT, ERCP is the first choice of treatment. Some technical modifications are required to complete the procedure as in a usual case.

\section{Ethics}

Informed Consent: After obtaining patient's consent, both procedures were performed by the authors.

Peer-review: Externally peer-reviewed.

\section{Authorship Contributions}

Concept: H.E., P.T., Design: H.E., P.T., Supervision: H.E., P.T., Materials: H.E., Data Collection or Processing: H.E., Analysis or Interpretation: P.T., Literature Search: H.E., Critical Review: P.T., Writing: H.E.

Conflict of Interest: No conflict of interest was declared by the authors.

Financial Disclosure: The authors declared that this study received no financial support.

\section{References}

1. Reddy A, Paramasivam S, Alexander N, Abhilash, Ravisankar V, Thillai M. Management of a patient with situs inversus totalis with acute cholecystitis and common bile duct stones: A case report. 
Int J Surg Case Rep 2014; 5: 821-3. 1016/j.ijscr.2014.08.004. Epub 2014 Aug 26.

2. Mayo CW, Rice RG. Situs inversus totalis: a statistical review of data on seventy-six cases with special reference to disease of the biliary tract. Arch Surg 1949; 58: 724.

3. Hu Y, Zeng H, Pan XL, Lv NH, Liu ZJ, Hu Y. Therapeutic endoscopic retrograde cholangiopancreatography in a patient with situs inversus viscerum World J Gastroenterol 2015; 2: 5744-8.
4. Akcakaya A, Okan I, Şahin M, Karakelleoğlu A, Baş G. The Use of ERCP in patients with situs inversus totalis associated with obstructive biliary pathologies. Balkan Med J 2011; 28: 227-8.

5. Mohanprasad VG, Patil P, Prasad M, Shanker GK. ERCP in situs Inversus can be performed in usual left lateral position. J Dig Endosc 2012; 3: 42-4.

6. Fiocca F, Donatelli G, Ceci V, Cereatti F, Romagnoli F, Simonelli L, et al. ERCP in total situs viscerum inversus. Case Rep Gastroenterol 2008; 2 : 116-20. 